\title{
Beyond Labor History's Comfort Zone? Labor Regimes in Northeast India, from the Nineteenth to the Twenty-First Century
}

\author{
Willem van Schendel
}

What is global labor history about? The turn toward a world-historical understanding of labor relations has upset the traditional toolbox of labor historians. Conventional concepts turn out to be insufficient to grasp the dizzying array and transmutations of labor relations beyond the North Atlantic region and the industrial world. Attempts to force these historical complexities into a conceptual straitjacket based on methodological nationalism and Eurocentric schemas typically fail. ${ }^{1}$

A truly "global" labor history needs to feel its way toward new perspectives and concepts. In his Workers of the World (2008), Marcel van der Linden provides us with an excellent account of the theoretical and methodological challenges ahead. He makes it very clear that labor historians need to leave their comfort zone. The task at hand is not to retreat into a further tightening of the theoretical rigging: "we should resist the temptation of an 'empirically empty Grand Theory' (to borrow C. Wright Mills's expression); instead, we need to derive more accurate typologies from careful empirical study of labor relations." ${ }^{2}$ This requires us to place "all historical processes in a larger context, no matter how geographically 'small' these processes are."3

This chapter seeks to contribute to a more globalized labor history by considering such "small" labor processes in a mountainous region of Asia. My aim is to show how these processes challenge us to explore beyond the comfort zone of "labor history," and perhaps even beyond that of "global labor history"

* International Institute of Social History and University of Amsterdam. I wish to thank Joy L.K. Pachuau for her advice. This chapter uses visual material collected jointly for our book The Camera as Witness: A Social History of Mizoram, Northeast India (Delhi, etc, 2015).

1 Marcel van der Linden, Workers of the World: Essays toward a Global Labor History (Leiden/ Boston, 2008), 3-10.

2 Van der Linden, Workers of the World, 36.

3 Van der Linden, Workers of the World, 6.

(C) WILLEM VAN SCHENDEL, 2018 | DOI:10.1163/9789004386617_010

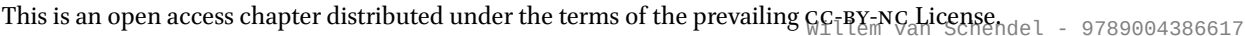


as outlined by Van der Linden. ${ }^{4}$ We are reminded of the urgency of studying such regions - and the long road ahead for "global history" - when we see "the mismatch between our historical curiosity and the population of the world's major regions." Clossey and Guyatt suggest that over three quarters of historical research in North America and the UK deals with the North Atlantic region, home to 17 percent of humankind, and only 4 percent of historical research deals with South and Southeast Asia, home to a third of humankind. ${ }^{5}$

The region in question is Mizoram, one of the 29 states (or provinces) of India. It is in the far northeast of that country, and on three sides lie territories governed by Myanmar (Burma) and Bangladesh. Mizoram is a good place to reassess methodological nationalism, as culturally it is starkly different from the "India" that labor historians have so far studied and theorized. Historically, labor relations in this region have much in common with those in an expanse sometimes referred to as the Extended Eastern Himalayas, a culture area stretching from northeast India and Bangladesh to Myanmar and southwest China. ${ }^{6}$ By looking at the evolution of labor relations in Mizoram over the last 150 years, we can provide a modest corrective to the ills of both Eurocentrism and Indiacentrism in labor history. Van der Linden identifies "neglect," "prejudice," and "implicit assumptions" as the major ills of Eurocentrism; ${ }^{7}$ these can be applied equally to what inhabitants of Northeast India might call Mainland-India-centrism.

The case of Mizoram alerts us to similarities in labor relations across borders and within culture areas, reminds us of the historical contingency of contemporary nation states, and points to a lack of consideration given to labor in many local historiographies. Labor relations in Mizoram also draw our

4 See also Marcel van der Linden, "The 'Globalization' of Labour and Working-Class History and its Consequences," International Labor and Working-Class History 65 (2004): 136-156; Willem Van Schendel, "Stretching Labour Historiography: Pointers from South Asia," International Review of Social History $5^{1}$ (2006): 229-261; Van der Linden, Workers of the World, 360.

5 Luke Clossey and Nicholas Guyatt, "It's a Small World After All: The Wider World in Historians' Peripheral Vision," American Historical Association, accessed July 11, 2018, https:// www.historians.org/publications-and-directories/perspectives-on-history/may-2013/its-a -small-world-after-all and http://smallworldhistory.org/.

6 Stuart Blackburn, "Oral Stories and Culture Areas: From Northeast India to Southwest China," South Asia:Journal of South Asian Studies 30, no. 3 (2007): 419-437.

7 Neglect: "There is only attention for part of the world; the author assumes that the history of 'his piece of the world' can be portrayed without giving any attention to the rest." Prejudice: "The authors do consider global connections, but nevertheless believe Greater Europe (including in this North America and Australasia) 'shows the way." Implicit assumptions: "General beliefs about historical experience which, allegedly, have been confirmed time and again by previous scientific research, and therefore can be taken for granted": Van der Linden, Workers of the World, 8-9. 
attention to both the difficulties in generalizing familiar categories (for example, "slavery"8), and the dangers of applying evolutionary typologies. Lastly, the case of Mizoram throws light on an enduring type of labor relation, voluntary communal labor, which historians of labor rarely scrutinize.

I present brief sketches of Mizoram's labor regime as it evolved during three successive periods. The purpose is to show that global labor history cannot advance unless we shed assumptions of unilinear transformation, and until we recognize the importance of dealing with the cultural meanings of laborand not just its economic forms - in any attempt at comparing labor relations across time and space. This requires labor historians to improve their crosscultural sensibilities, re-examine their methodologies, and broaden their use of sources. ${ }^{9}$

\section{2 \\ Pre-colonial Labor Relations}

In the 18gos, the British invaded the territory of what is now Mizoram (up to the 1950s: Lushai Hills ${ }^{10}$ ). Before this time, the region had never been under state control. Its village-sized polities were self-governing and the regional labor regime combined household self-employment (mainly subsistence agriculture), servile labor, and communal labor. All households had access to land, so they acted as largely self-providing production teams. This was a region of abundant land and perennial labor shortages and —in the absence of a labor market—such shortages were met by servitude and communal labor.

8 For a recent critique of definitions of slavery, see Marcel van der Linden, "Dissecting Coerced Labor," in On Coerced Labor: Work and Compulsion after Chattel Slavery, eds. Marcel van der Linden and Magaly Rodriguez García (Leiden/Boston, 2016), 293-322.

$9 \quad$ Van der Linden makes this point when discussing changing labor relations in Papua New Guinea: "ethnographers have much to offer labor historians, including over 21,000 brief and extended studies on Papua New Guinea alone. Global Labor History can access much more relevant information than one might think." Van der Linden, Workers of the World, 358 .

10 The British named the region after the largest language community, the Lushai. They defined speakers of this language as a "tribe," even though the term was highly problematic and many fluid group identities were subsumed under it. Over time, tribal selfidentification flourished and solidified, partly because Lushai became the language of education: Lushai speakers developed a sense of belonging and attempted (quite successfully) to bring other groups into the fold. They insisted on the appellation of "Mizo" for this larger grouping. Today not all groups in Mizoram [Mizo Land] identify as Mizo, however, and self-identification remains remarkably malleable. 
Various forms of servitude were practiced in pre-colonial Mizoram, and they bore a family resemblance to practices across the Extended Eastern Himalayas. The exact evolution of these regional practices is hard to establish, because most societies were preliterate. Historical evidence is scarce: whatever we know comes from oral traditions and external, often post-invasion, written sources. It is clear, however, that servitude took different shapes across the region. ${ }^{11}$ In Mizoram it comprised two types, servitude-by-capture $(s a l)$ and servitude-by-refuge (bawi, pronounced "boi"). ${ }^{12}$

Servitude-by-capture (sal). The small polities of the region engaged in what has been called "slave-gathering warfare."13 They raided the villages of other groups to safeguard their own autonomy and in search of labor power. Such conflicts became more frequent in the nineteenth century. Some involved hunting in areas in the foothills ${ }^{14}$ where European tea planters had intruded, and which British authorities claimed as colonial territory. ${ }^{15}$ Construed as

11 Gordon P. Means, "Human Sacrifice and Slavery in the 'Unadministered' Areas of Upper Burma During the Colonial Era," Sojourn:Journal of Social Issues in Southeast Asia 15, no. 2 (2000): 184-221; Mandy Sadan, Being and Becoming Kachin: Histories Beyond the State in the Borderworlds of Burma (Oxford, 2013), 59-63, 80-82, 223-224.

12 These are the terms in the Duhlian dialect of the Lushai language. The Mizoram region was (and is) multilingual, so it is important to acknowledge that there were many local terms for forms of servitude. Today the Duhlian dialect (now known as the Mizo language) is the official language of Mizoram. When missionaries first attempted to write down this language in Roman script, they chose to transcribe the "o" as "aw," mirroring the practice in their native Welsh. See Indrani Chatterjee, "Slavery, Semantics and the Sound of Silence," in Slavery and South Asian History, eds. Indrani Chatterjee and Richard M. Eaton (Bloomington, 2007), 287-316. Probably the first written reference to the terms ("sul" and "boi") can be found in T.H. Lewin, Progressive Colloquial Exercises in the Lushai Dialect of the "Dzo" Or Kúki Language, with Vocabularies and Popular Tales (notated) (Calcutta, 1874), 80-81 and passim.

13 Bryce Beemer, "Southeast Asian Slavery and Slave-Gathering Warfare as a Vector for Cultural Transmission: The Case of Burma and Thailand," Historian 71, no. 3 (2009): 481-506; Andrew Turton, "Violent Capture of People for Exchange on Karen-Tai Borders in the 1830s," Slavery \& Abolition 24, no. 2 (2003): 69-82.

14 Guite argues that large forested areas, which the British considered uninhabited, were in fact hunting grounds that the hill people deliberately left uncultivated, a strategy well understood by lowlanders. British incursions into these buffer zones challenged the hill people's spatial and sacred notions of sovereignty—and thereby triggered negotiations and, more rarely, warfare: Jangkhomang Guite, "Colonialism and Its Unruly? The Colonial State and Kuki Raids in Nineteenth Century Northeast India," Modern Asian Studies 48, no. 5 (2014).

15 N.E. Parry, The Lakher (London:, 1932), 7-12, 202-221; David Vumlallian Zou, "Raiding the Dreaded Past: Representations of Headhunting and Human Sacrifice in North-East India," 
attacks on "British subjects," these conflicts triggered brutal British invasions of the highlands. ${ }^{16}$ Between the 1890 and 1930 , these invasions succeeded in subjugating the many polities in Mizoram. ${ }^{17}$

Before colonization, captives taken in war-predominantly children and women because enemy men were often killed in combat ${ }^{18}$ - became the personal property of their captors (Figure 9.1). ${ }^{19}$ Their labor power was an important economic and social resource. A challenge to the master's ownership would meet with strong village opposition, as British officials found out.

On one occasion [in the early 186os] my predecessor, Captain Graham, was visiting a Kookie [Lushai or Mizo] village, and he discovered that they held some British subjects in captivity. On demanding their release,

Contributions to Indian Sociology 39, no. 1 (2007); Soong Chul Ro, Naming a People: British Frontier Management in Eastern Bengal and the Ethnic Categories of the Kuki-Chin, 17601860 (Ph.D. thesis: University of Hull, 2007), Chapter 6; Jangkhmang Guite, "Civilisation and its Malcontents: The Politics of Kuki Raid in Nineteenth Century Northeast India," The Indian Economic and Social History Review 48, no. 3 (2011): 339-376; Guite, "Colonialism and Its Unruly." Among the Mara (Lakher), war captives were known as sei. For the eighteenth century, see Willem van Schendel, ed., Francis Buchanan in Southeast Bengal (1798): His Journey to Chittagong, the Chittagong Hill Tracts, Noakhali and Comilla (Dhaka, 1992), 16, 93, 112-113. For examples of "raids into British-held territory," see Annual Report on the Administration of the Bengal Presidency for 1863-64 (O.T. Cutter, Military Orphan Press, 1865), 164-168; "Copy of Correspondence between the India Office and the Government of India, on the Subject of the Irruption of Hill Tribes into Cachar," Accounts and Papers of the House of Commons (Session 9 February-21 August 1871), vol. 14 (London: House of Commons, 1871); "Copy of Further Correspondence on the Subject of the Looshai Raids and the Consequent Hostilities," in Continuation of Parliamentary Paper, No. 398, of Session 1871 (London: House of Commons, 1872); Alexander Mackenzie, History of the Relations of the Government with the Hill Tribes of the North-East Frontier of India (Calcutta, 1884), 287-365; Guite "Colonialism and Its Unruly."

16 R.G. Woodthorpe, The Lushai Expedition, 1871-1872 (London, 1873); Mackenzie, History of the Relations.

17 The southernmost villages remained "independent and unadministered until the last few years" and they were "loosely administered" in the 1930s (Parry, The Lakher, vii, 12; cf. ix). The persistence of sal servitude here is attested to by the British declaration that its signing of the Slavery Convention of the League of Nations (1926) was not binding for "a small tract in the South of the Lushai Hills District [Mizoram]": League of Nations, Slavery Convention (Geneva, 1926), 6.

18 J. Shakespear, The Lushei Kuki Clans (London, 1912), 50. Lorrain indicated that the Mara (Lakher) in southern Mizoram preferred to capture children because these were less likely to escape: Reginald A. Lorrain, Five Years in Unknown Jungles for God and Empire (London, 1912), 166.

19 Parry, The Lakher, 222-223; Lian H. Sakhong, In Search of Chin Identity: A Study in Religion, Politics and Ethnic Identity in Burma (Copenhagen, 2003), 41-42; Lalhrilmoi Hrangchal "Sal: Slavery in the Lushai Hills," International Journal of Research 1, no. 10 (2014):1903-1931. 


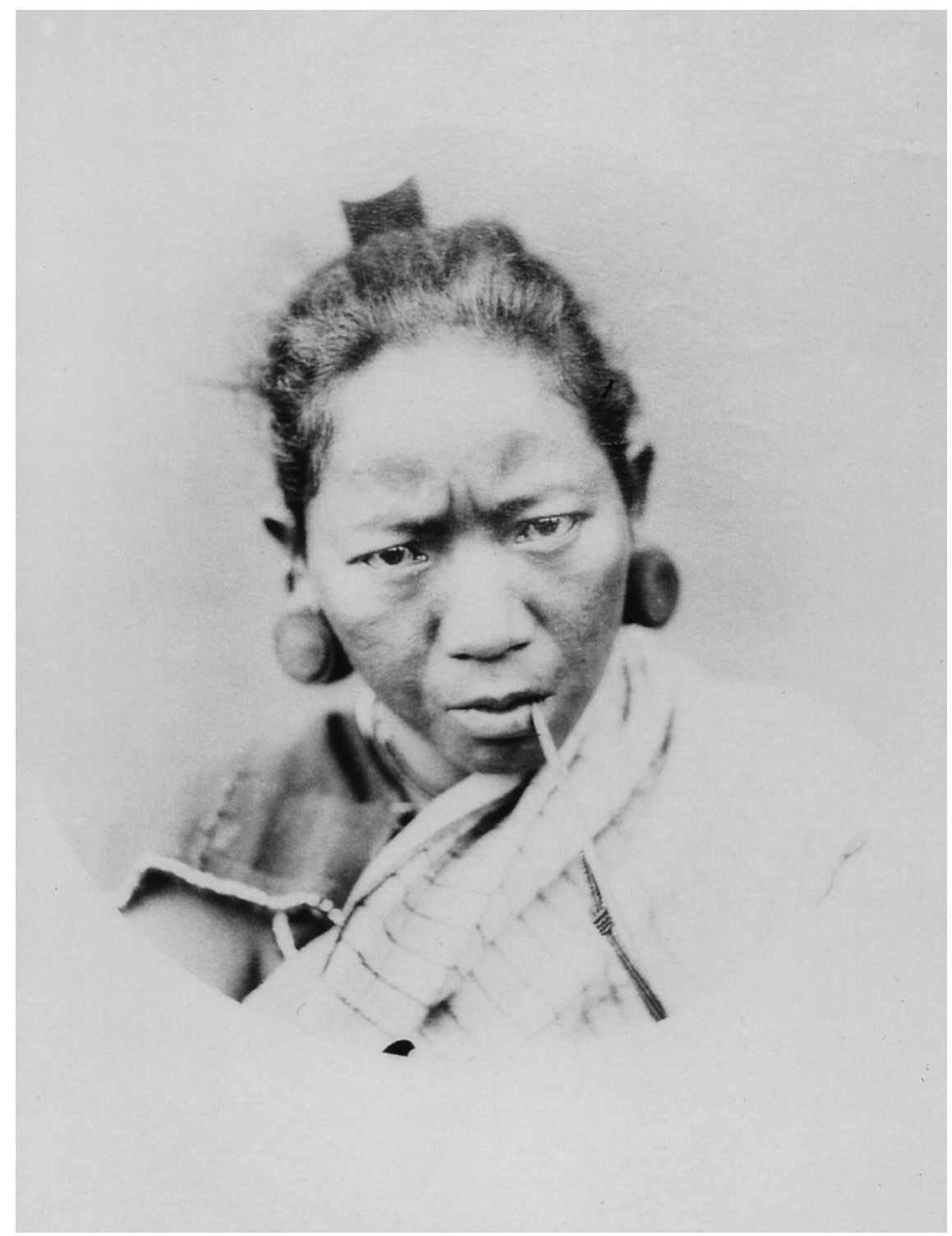

FIGURE 9.1 A war captive (sal), 1866.

PHOTOGRAPH BY T.H. LEWIN, REPRODUCED BY PERMISSION OF THE LEWIN FAMILY PAPERS, UNIVERSITY OF LONDON LIBRARY, UK

Note: This woman, whose name is unknown, was a Lushai who was taken in war by a neighboring group, the Shendu (Mara). See also Joy L.K. Pachuau and Willem van Schendel, The Camera as Witness: A Social History of Mizoram, Northeast India (New Delhi, etc., 2015), 27. 
however, the Chief refused to let them go; and Captain Graham equally refusing to go without them, things began to look mischievous. At length the Chief in a rage betook himself off to his house, and the big gong began to toll. Captain Graham describes the effect as miraculous: every woman and child disappeared from sight as if by magic, and the Lhoosai, with their weapons in their hands, came crowding to the Chief. Matters, however, were eventually arranged on a peaceable footing, and the captives were released. ${ }^{20}$

Captives did not own possessions and their servitude was heritable. They could be traded, but it is unclear whether or not this was a rare occurrence. ${ }^{21}$ Pre-colonial Mizoram had a barter economy, so the price of captives was not expressed in money, but in terms of gayals (semi-wild bison, also known as mithuns) or guns. "A slave among them [the Shendu or Mara] is valued at eight muskets or two guyals. They appear to be ignorant of money or its value."22 "I am told that when guns first made their appearance in the hills the western tribes used to exchange their sāl with the eastern tribes for guns, one strong sāl being worth two guns." ${ }^{23}$ There is considerable evidence that captives were well treated. ${ }^{24}$ According to Lewin,

A remarkable circumstance transpired with reference to the people held in captivity by the Lushais, viz., that all unite in describing the treatment they received as kind in the extreme. In no case has it been ascertained that any violence had been offered to a female captive, while, as the list shows, many of them have actually married, and becoming incorporated with the tribe, decline positively to be released. The captives given up by

$20 \quad$ T.H. Lewin, The Hill Tracts of Chittagong and the Dwellers Therein; with Comparative Vocabularies of the Hill Dialects (Calcutta, 1868), 104, cf. 35-36. The text of this book is largely the same as Lewin 1870 .

21 Lewin, Progressive Colloquial Exercises, 80.

22 Lewin, The Hill Tracts, 114.

23 Shakespear, The Lushei, 50. See also Parry, The Lakher, 205, 585. For more on the connection between the spread of guns and the trade in sal, see Hrangchal, "Sal: Slavery."

24 The term sal was also employed in a figurative way: "Should several children have died young, the parents will carry the next baby and deposit it in a friend's house, and then come and ask, 'Have you a slave to sell,' and purchase it for a small sum. This is supposed to deceive the Huais [demons causing sickness]. Such children's names always begin with Suak, and, judging from the frequency with which such names are met, the custom must be a very common one": Shakespear, The Lushei, 126. The practice was known as salah zuar or suakah zuar: Reginald A. Lorrain, Dictionary of the Lushai Language (Calcutta, 1940), 410, 420. 
the Southern Howlongs had to be brought forcibly into the camp, and clung to their Lushai friends, weeping piteously and entreating that they might not be made over to us. ${ }^{25}$

Those captives who attempted to flee, however, were severely dealt with. Masters would punish those whom they recaptured by hobbling them, by means of wooden fetters, or even putting them to death. ${ }^{26}$

Servitude-by-refuge (bawi). The second, much larger servile category was known as bawi. People in this category were in a better position than war captives, not least because they could not be sold and because they were from within the community. ${ }^{27}$ This type of servitude came in three different forms: distress servants, sanctuary servants, and deserter servants. Only village chiefs were entitled to keep servants of these categories. ${ }^{28}$

Distress servants, or dependents "living in the village chief's house," formed the majority of bawi. ${ }^{29}$ They were villagers who could not support themselves-orphans, widows without relatives, or people who had incurred debts—and therefore took refuge in the chief's house. ${ }^{30}$ This form of servitude

25 Report from Captain T.H. Lewin, Civil Officer, Right Column Lushai Expedition, to the Secretary to the Government of Bengal, No. 22, dated Chittagong, the 26th March, 1872: Reproduced in Mackenzie, History of the Relations, 469. See also Lewin, Progressive Colloquial Exercises, 80-81; Woodthorpe, The Lushai Expedition, 237-238, 317; A.G.E. Newland and J.D. MacNabb, The Image of War, or Service on the Chin Hills (Calcutta, 1894), 54; Bertram S. Carey and H.N. Tuck, The Chin Hills: A History of the People, Our Dealings with Them, Their Customs and Manners, and a Gazetteer of Their Country (Rangoon, 1896), 230.

26 Lorrain, Five Years, 8, 82, 165-166. See also Woodthorpe, The Lushai Expedition, 181; Parry, The Lakher, 11, 222-223.

27 Shakespear, The Lushei, 46-49. Earlier indications of the bawi system can be gleaned from the observations of Buchanan in the 1790s and Lewin in the 186os: Van Schendel (ed.), Francis Buchanan, 89-90, 93; Lewin, The Hill Tracts, 33-35.

28 Chiefs could afford to keep large numbers of dependents, because even if their labor did not entirely provide for their upkeep, the chief had various sources of income in addition to returns from the land: a rice tax on each cultivator, a share in each animal shot or trapped in the village, a due on salt, and fines that rule-breaking villagers had to pay. This extra income was also expended on prestige-enhancing feasts. Parry, The Lakher,

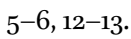

29 These were known by various names, such as chhungte, inawm, and inpuichhung (living in the big house), lalchhung (living in the chief's house), or chhiahhlawh (servant).

3o There are no indications that such debts were in money, because little or no money seems to have been circulating in this region, unlike in the adjacent Chittagong and Arakan hills, which were in direct contact with the thoroughly monetized coastal plains. For more information on barter and the absence of money in pre-colonial Mizoram: Lewin, The Hill Tracts, 114; Woodthorpe, The Lushai Expedition, 319; R.C. Temple, "Beginnings of Currency," The Journal of the Anthropological Institute of Great Britain and Ireland 29, no. 1/2 
constituted the pre-colonial social security system: Bawi servants were guaranteed shelter and food for the rest of their life. ${ }^{31}$ They were treated reasonably well, because they were free to move from one chief's house to another. Other chiefs welcomed bawi, because a large number of servants increased the importance of their village and their household's labor power. ${ }^{32}$ Bawi were allowed to own property and they could set up their own households after having worked for the chief for a number of years. ${ }^{33}$ Such "separate dependents" still owed their master certain services and gifts, and one or more of their children would be bawi. There were two ways of ending this form of servitude: by buying freedom - the price often being a gayal or its equivalent in other goods - or by being adopted by the chief. ${ }^{34}$

Sanctuary servants were those who had committed a serious crime, for example, murder or theft, and had sought refuge in the chief's house to escape revenge. ${ }^{35}$ This form of servitude was part of the pre-colonial system of justice. ${ }^{36}$ Sanctuary servants were not absorbed into the chief's household, but were settled nearby, under his or her protection. Their children were always considered bawi.

Deserter servants were men who, during a war, had deserted the losing side to join the victors by promising that they and their descendants would be servants. ${ }^{37}$ They did not live in the chief's house, but unlike the "separate dependents" and sanctuary servants, their daughters were usually not servants.

The system of distress servitude meant that pre-colonial Mizoram lacked footloose workers, but this was not an egalitarian society. The village chiefs, who belonged to a few lineages, considered their fellow villagers-self-providing

(1899): 101-102; Lorrain, Five Years, 89-90; Zalawra, “Titi Phungleng," Mizo leh Vai (December 1922): 135 .

31 Shakespear, The Lushei, 47; Lorrain, Five Years, 166. According to Verghese and Thanzawna, "to the Lushai [Mizo], the word 'Bawi' meant 'Pauper": C.G. Verghese and R.L. Thanzawna, A History of the Mizos, 2 vols. (New Delhi, 1997), I, 39; A.G. McCall, Lushai Chrysalis (London, 1949), 130.

32 For an example, see Lewin, Progressive Colloquial Exercises, 80.

33 They were known as inhrang bawi or "separate servant."

34 Lewin, Progressive Colloquial Exercises, 80; Shakespear, The Lushei, 47-48.

35 Known as chem-sen bawi, referring to a large axe or machete used as a weapon.

36 Servitude of this kind can be understood as an addition to the ten variants already identified in Van der Linden, "Dissecting Coerced Labor": 298-306.

They were known as tuklut bawi, or "enter by promising" servants. 
agriculturalists - as their subjects, and they thought of their servants being significantly below that status. This was a pattern of social distinction throughout the region, but among the Lushai (the majority population of Mizoram) it appears to have been comparatively muted. Commoners were relatively self-assured, and chiefs less powerful than in some neighboring communities: "A chief who disregards custom and oppresses the villagers will speedily lose the bulk of his subjects. The Lushai are accustomed to migrate freely from village to village and this custom affords a very salutary check on too arbitrary a use of power." 38

Even so, the chief could commandeer the labor power of fellow villagers to have his house built and his fields cultivated, but also for community work, such as repairing the bachelors' communal living quarters (zawlbuk), ${ }^{39}$ cutting a path through the jungle, making a tiger trap, or constructing a weir in the river. In addition, all able-bodied men were at his disposal for warfare or hunting expeditions. ${ }^{40}$ None of this work was paid for, but in return the chief would occasionally give a village feast. ${ }^{41}$

Community service (hnatlang ${ }^{42}$ ) was public work in which everyone was expected to take part. Much of it took place without the chief's involvement. Neighbors helped each other in constructing a hut or weeding a plot of land, the reward being a meal or helpings of rice beer and the promise of returning the favor when needed. ${ }^{43}$ Voluntary communal labor was the everyday social expression of the local ethical code (tlawmngaihna), which stressed the obligation to be self-sacrificing, stoical, brave, industrious, generous, and sharing. One characterization of tlawmngaihna is "an ideal of life in which a man could not be outdone in doing well to others. When a man is Tlawmngai, one cannot

38 N.E. Parry, A Monograph on Lushai Customs and Ceremonies [1928] (Calcutta, 1976), 1-2, 14-17. See also Lewin, The Hill Tracts, 100. According to Shakespear, "The Lakhers, in common with the Chins, are less democratic than the Lushais and their cognates. The power of the chiefs is greater, and the chiefs' relatives and other wealthy people form a kind of peerage and lord it over the lesser fry, being seldom interfered with unless their doings endanger the interests of the chief": Shakespear, The Lushei, 216.

39 Often the largest hut in a village; unmarried young men socialized, learned, and slept there.

40 This was especially true of the residents of the bachelors' living quarters: "As all the young men are concentrated there, they are always available for any unexpected emergency or for any urgent work": Parry, A Monograph, 9.

41 Parry, A Monograph, 6, 12.

42 Zaichhawna Hlawndo, "A Study of the Cultural Factors in the Foreign Missions Thinking of the Mizoram Presbyterian Church" (Ph.D. Thesis, University of Birmingham, 2011), 41.

43 C. Nunthara, Impact of the Introduction of Grouping of Villages in Mizoram (Guwahati, 1989), 53-54. 
defeat him in doing well to others, and that self-sacrifice sometimes demands life itself." ${ }^{44}$ Such community-sustaining behavior was essential in these tough mountains: Its inescapability was reflected in the popular saying "sem sem, dam dam, ei bil, thi thi"45 (share equally, otherwise you die).

\section{The Pre-colonial Labor Regime}

Before the 18gos, the labor regime of Mizoram consisted of household selfemployment, servile labor, and communal labor (see Table 9.1); wage labor was absent and so was proletarianization. ${ }^{46}$ There was no "free labor." The local economy had long been influenced by the expansion of world capitalismmainly through trade - but this had effected neither a transformation of labor relations nor a monetization of the local economy.

TABLE 9.1 Mizoram. Pre-colonial labor regime. Pre-colonial labor relations ended in the 189os, except for some areas in the south, where they continued up to c. 1930.

\begin{tabular}{|c|c|c|c|}
\hline \multicolumn{4}{|c|}{ Household labor } \\
\hline \multirow{4}{*}{ Servitude } & \multicolumn{2}{|l|}{ Servitude-by-capture } & \multirow{2}{*}{$\begin{array}{l}\text { sal } \\
\text { inpuichhung } \\
\text { bawi, lalchhung } \\
\text { bawi }\end{array}$} \\
\hline & \multirow{3}{*}{$\begin{array}{l}\text { Servitude-by-refuge } \\
\text { (bawi) }\end{array}$} & $\begin{array}{l}\text { Distress } \\
\text { servants }\end{array}$ & \\
\hline & & $\begin{array}{l}\text { Sanctuary } \\
\text { servants }\end{array}$ & chem-sen bawi \\
\hline & & $\begin{array}{l}\text { Deserter } \\
\text { servants }\end{array}$ & tuklut bawi \\
\hline \multicolumn{3}{|c|}{ Communal labor } & hnatlang \\
\hline
\end{tabular}

44 R.L. Thanmawia, "The Mizo Value (As Reflected in Oral Traditions)," in History and Identity Formation in North-East India, ed. J.V. Hluna (New Delhi, 2013), 273-279 (quoting K.C. Lalvunga). For various other definitions of this mindset, see Hlawndo, "A Study of the Cultural Factors," 44-46; Parry, A Monograph, 19-21.

45 Hlawndo, "A Study of the Cultural Factors," 43.

46 In each village there were a few individuals who did some work that was remunerated, but it would be a misnomer to refer to their services as wage labor. The blacksmith, the priest, and (sometimes) the herald would get a basket of paddy from each household annually in exchange for their services to the community. Parry, A Monograph, 6-7. 
The 1890 s were a period of rapid and violent transformation. The British managed to establish their rule in most of Mizoram, disrupting and reordering the labor regime.

\subsection{Servitude}

Servitude-by-capture ( $\mathrm{sal}$ ) came to an end, because the colonial rulers prohibited it and because the internecine warfare that had provided a fresh supply of captives had become a thing of the past. ${ }^{47}$ Some sal stayed with their former masters and became integrated into their villages, others returned to their own villages. ${ }^{48}$

Servitude-by-refuge (bawi) underwent considerable change. One of the three subgroups, deserter servants, was formally discontinued "but their duties weigh so lightly on them that they seldom claim their release, and in their case, as in that of the 'sāl,' the class, receiving no fresh recruits, will soon cease to exist." 49 The second subgroup, sanctuary servants, was also disallowed and "whenever one has claimed protection he has been released." ${ }^{50}$ A new colonial justice system was gradually taking over, and those who committed serious crimes could no longer take refuge in a chief's house and live nearby under his or her protection.

It was the third and largest subgroup, distress servants, that was allowed to persist. This was remarkable, because the British understood this form of servitude-by-refuge quite well and had abolished it when they took over neighboring areas: the Chittagong Hill Tracts, the Chin Hills, and Arakan. ${ }^{51}$

47 According to Turton, this was a more general pattern: "the violent 'razzia' form of slave raiding and trading was the first to disappear with the expansion of European influence in the region [Southeast Asia]": Turton, "Violent Capture," 70.

48 On the fluidity of pre-colonial group identities and the ease with which individuals could take on a new identity by means of the practice of saphun, which involved adopting the guardian spirit (sakhua) of another group, see Joy L.K. Pachuau, Being Mizo: Identity and Belonging in Northeast India (New Delhi, 2014). On former sal returning to their old villages, see Shakespear, The Lushei, 41. See also Parry, The Lakher, 228; McCall, Lushai Chrysalis, 64-65.

49 Shakespear, The Lushei, 49.

5o Shakespear, The Lushei, 49.

51 It was not a case of failed recognition, as Jacobsen argues for Cambodia: Trude Jacobsen, "Debt Bondage in Cambodia's Past—and Implications for its Present," Studies in Gender and Sexuality 15 (2014): 33. On the Chittagong Hill Tracts (now in Bangladesh), see Lewin, The Hill Tracts, 34-35; Parry, The Lakher, 18. On the Chin Hills (now the Chin State of Myanmar), see Bertram S. Carey and H.N. Tuck, The Chin Hills, 203-204; C. Crosthwaite, 
One reason for preserving it in Mizoram was the specific "light" form of colonial administration there, in which a small cohort of British soldiers-administrators relied heavily on the power of local chiefs who, in turn, relied on the labor of their servants and on the prestige these bestowed on their masters (Figure 9.2). ${ }^{52}$ Fear of revolt by chiefs and the cost of releasing servants (and consequently having to deal with Mizoram's poor) made the colonial authorities take a lenient view of this form of servitude: "the custom seems well suited to the people and provides for the maintenance of the poor, old, and destitute, and it would be extremely unwise to attempt to alter it." 53

Not all observers shared this indulgent view. In what became known as the "Bawi Controversy," a missionary, faced with chiefs who forbade their bawi servants to become Christians, publicly challenged the colonial authorities by asserting that bawi servants were, in fact, slaves. ${ }^{54}$ He proceeded to liberate several of them. ${ }^{55} \mathrm{He}$ also urged Christian chiefs to free their bawi-and some did (Figure 9.3).

The colonial establishment was not amused. The highest local official flatly denied that bawi servitude could be equated with slavery, and eventually forced the missionary to leave Mizoram. ${ }^{56}$ This controversy was not, however, merely a definitional squabble between a zealous missionary activist and local officials. It had far-reaching consequences, because it touched on wellestablished legal provisions prohibiting slavery in both Britain and India. The controversy led to a campaign in Britain and debates in Parliament during

The Pacification of Burma (London, c. 1912), 324. On Arakan (now the Rakhine State of Myanmar), see Gwynne W. Hughes, The Hill Tracts of Arakan (Rangoon, 1881), 20-21.

52 Most distress servants (inpuichhung bawi) appear to have been women and children. Chatterjee, Slavery and South Asian History, 330.

53 Shakespear, The Lushei, 49. See also McCall, Lushai Chrysalis, 121-131, who describes bawi servitude as "in most cases, almost paternal care."

54 Chatterjee, "Slavery, Semantics"; Sajal Nag, "Rescuing Imagined Slaves: Colonial State, Missionary and Slavery Debate in North East India (1908-1920)," Indian Historical Review 39, no. 1 (2012): 57-71; Sajal Nag, The Uprising: Colonial State, Christian Missionaries, and Anti-Slavery Movement in North-East India (1908-1954) (New Delhi, 2016); Kyle Jackson, "Colonial Conquest and Religious Entanglement: A Mizo History from Northeast India (c. 1890-1920)" (Ph.D. thesis, University of Warwick, 2016), 276n.

55 The colonial authorities had modified the rule that offering a gayal to the master terminated a family's servitude; now a sum of money (40 rupees) could be paid instead. Parry, The Lakher, 13 .

56 McCall, Lushai Chrysalis, 121-131; Chatterjee argues that mission authorities told him to leave: Indrani Chatterjee, Forgotten Friends: Monks, Marriages, and Memories of Northeast India (New Delhi, 2013), 320-324, 330. 


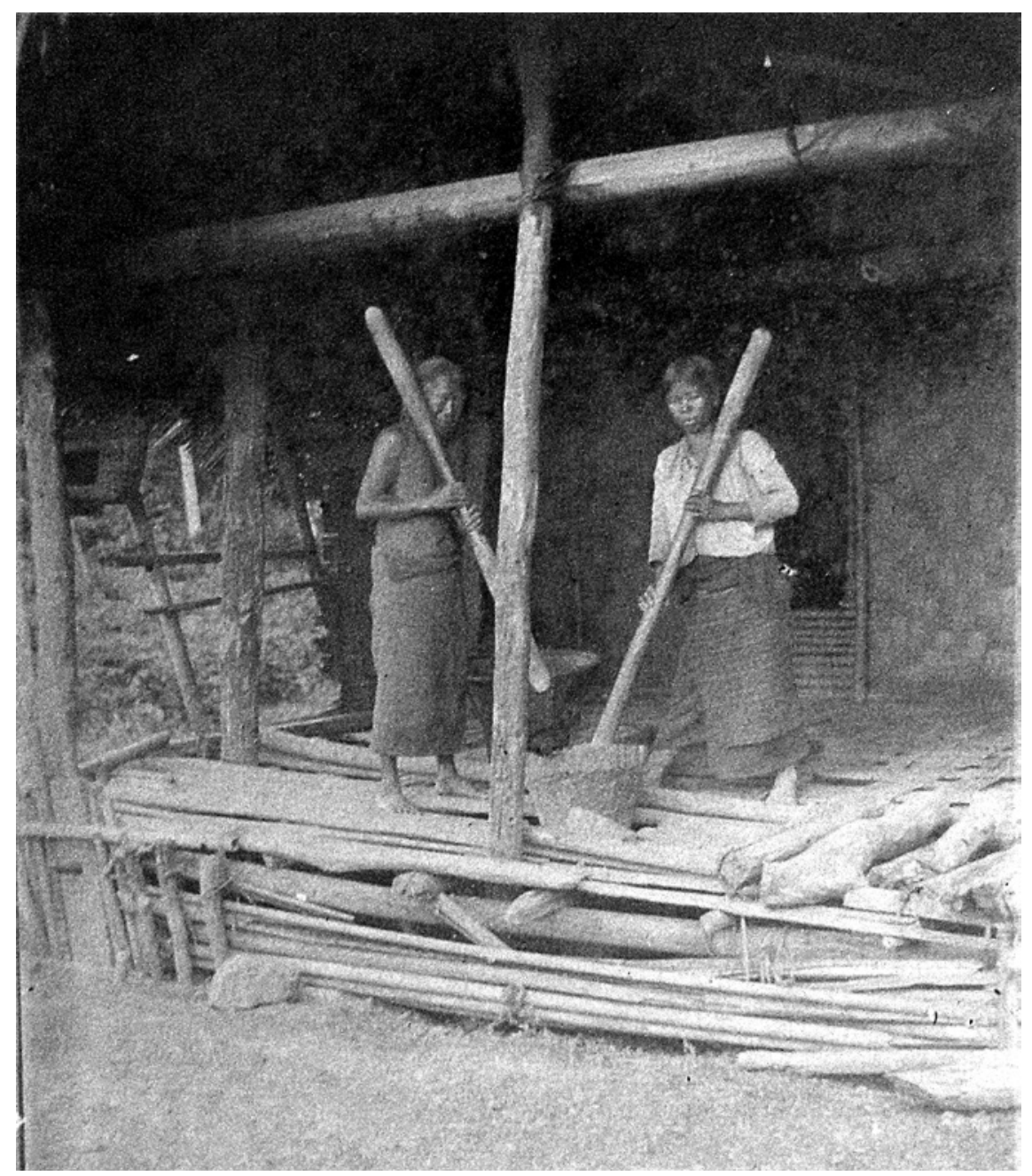

FIGURE 9.2 Mara woman and her servant pounding rice in Saikao (Serkawr), southern Mizoram.

PHOTOGRAPHER UNKNOWN. REPRODUCED BY PERMISSION OF THE LAKHER PIONEER MISSION COLLECTION, SAIKAO (SERKAWR), MIZORAM, INDIA

1913 and $1914 .{ }^{57}$ After World War I, the League of Nations began to scrutinize bawi servitude under its remit to abolish slavery worldwide, and Britain was

57 Nag "Rescuing Imagined Slaves"; Nag, The Uprising; Suhas Chatterjee, Mizo Chiefs and the Chiefdom (Delhi, 1995), 42-44; House of Commons Debates, 12 June 1913 (vol. 53, 1789-90); 7 August 1913 (vol. 56, 1887-8, 1899-190o); 7 July 1914 (vol. 64, 867); 23 July 1914 (vol. 65, 657-9); 3 August 1914 (vol. 65, 1800-2). 


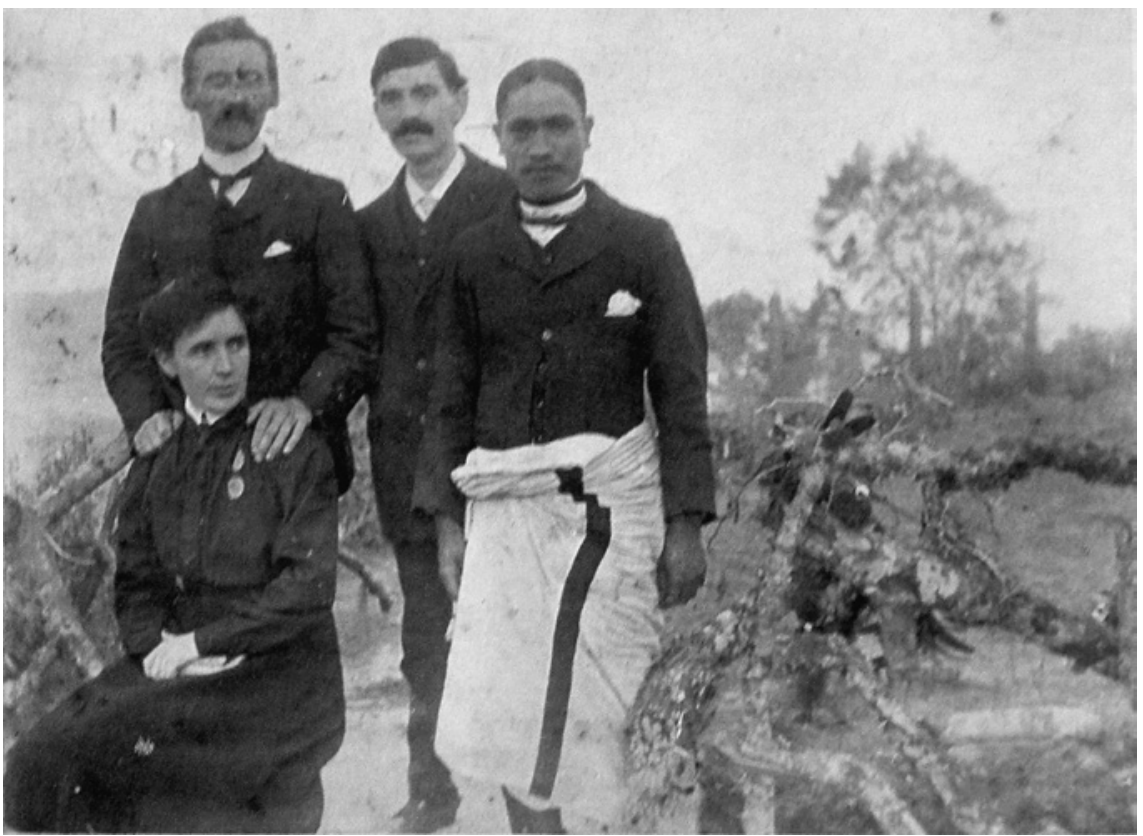

FIGURE 9.3 Anti-slavery activist with his wife and helper, together with a Christian chief who freed his bawi servants in 1909 .

LEFT TO RIGHT: MARY FRASER, DR. PETER FRASER, WATKIN R. ROBERTS, AND KHAWVELTHANGA. PHOTOGRAPHER UNKNOWN. REPRODUCED BY PERMISSION OF SYNOD ARCHIVES COLLECTION, AIZAWL, MIZORAM, INDIA

obliged to reiterate its disavowal of bawi servitude being a form of slavery. ${ }^{58}$ Meanwhile, back in Mizoram, the authorities discontinued using the word bawi "due to its association with the wider sense of slavery."59

\subsection{Communal Labor}

The British maintained communal labor for the chief, but codified and circumscribed chiefs' rights to demand it for their own benefit. ${ }^{60}$ Instead, communal tasks directed by the chief were to focus on repairing the bachelors' living

58 Gordon P. Means, "Human Sacrifice," 184-221. By contrast, when signing the Convention on Slavery in 1926, the British government implicitly acknowledged that they regarded sal servitude (which persisted in the southernmost region of Mizoram until they gained control there around 1930) as genuine slavery. See League of Nations, Slavery Convention, 6.

59 McCall, Lushai Chrysalis, 129.

6o Superintendent, Lushai Hills [A.G. McCall], Lushai Hills District Cover (Aizawl Theological College Archives, Aizawl, Mizoram, India, 1938), 23, 24. 
quarters (zawlbuk), the village forge (pum), the village school and teacher's house, clearing jungle, and fencing off the water supply. 61

Throughout the colonial period, communal labor without the chief's involvement continued to be an essential social institution. "It is the custom in Lushai villages for all people to help each other ... it is very shameful if people refuse to help." ${ }^{2}$ Reciprocal cooperation was especially important in agriculture, because without mutual assistance the work could not be done in time. ${ }^{63}$

\subsection{Forced Labor}

Under colonial rule, the two older labor relations-servitude and communal labor-were combined with two new forms: state-imposed forced labor and wage labor. Forced labor (corvée, impressed labor) was the most controversial. ${ }^{64}$ The new rulers saw it as a form of taxation that was fully justified and they made light of it:

You forced us to occupy your hills, we had no wish to come up here but you would raid our villages, so we had to come, and so now you have got [to] bear as much of the occupation as possible, you cannot expect us [to] spend the money of the people of the plains on importing coolies to do the work that you are too lazy to do except under compulsion. ${ }^{65}$

Labour by impressment is a part of the people's reasonable contributions to the Government in return for the services provided and on account of the almost insurmountable difficulty that would attend any attempt to create communications through the Hills capable of sustaining mechanical Transport ... The scale of impressed labour is a maximum of 10 days per year per house. A Lushai house generally contains 4 to 6 members of whom two may be males. There are at the time of writing some 22500 houses. From these figures it will easily be seen that even the maximum liability is very small and when it is realized further that the maximum has never yet had to be exacted the incidence of hardship can be said to be infinitesimal. ${ }^{66}$

61 Superintendent, Lushai Hills, 24.

62 Superintendent, Lushai Hills, 24-25.

63 C. Nunthara, Impact, 53-54.

64 There was also some privately imposed forced labor, mainly of children in missionary schools. Pachuau and Van Schendel, The Camera as Witness, 178-179. See also Catherine Koonar, "Using Child Labor to Save Souls: the Basel Mission in Colonial Ghana, 1855190o," Atlantic Studies 11, no. 4 (2014): 536-554.

65 J. Shakespear, Annual Report of the Lushai Hills for 1898-1899 (Shillong, 1899), 4, quoted in Sangkima, Mizos: Society and Social Change (1890-1947) (Guwahati, 1992), 78.

66 Superintendent, Lushai Hills, 97, 106. 
If we go by these figures, the annual forced-labor demand in colonial Mizoram came to some 600 man years, and the system involved the labor of tens of thousands of male villagers. ${ }^{67}$ People deeply resented and opposed coerced labor, not only because it was backbreaking work, but also because it came with the destruction of social hierarchies, humiliation, physical abuse, billeting, demands for women's sexual services, theft of livestock and rice, and disruption of agricultural work. ${ }^{68}$

A major task of coerced laborers was to act as porters for officials who regularly toured the area (Figure 9.4). ${ }^{69}$ Because of the very steep terrain-and the lack of level roads and wheeled traffic - travelers had to move arduously along trails, beds of rivulets, and bridle paths. ${ }^{70}$ Porters were supposed not to be forced to carry loads exceeding $50 \mathrm{lb}$., or to march for more than 15 miles a day, "except in very special circumstances." ${ }^{\text {"I }}$ In the 1930s, porters were remunerated at the rate of half a rupee a day. ${ }^{72}$

Forced labor took other forms as well, such as house building, clearing the jungle around military settlements, and carrying heavy building materials and agricultural produce. ${ }^{73}$ Officially, women were not to be recruited as forced

67 Kyle Jackson, “Globalising an Indian Borderland Environment: Aijal, Mizoram, 1890-1919," Studies in History 32, no. 1 (2016): 39-71; Jackson, "Colonial Conquest," 75, 109.

68 McCall, Lushai Chrysalis, 288; Parry, A Monograph, 6; Lalngurliana Sailo, "Economic Changes and Social Evolution: Mizoram (1870-1960)" (Ph.D. Thesis, Shillong, 2004), 116-118, 217; Chatterjee, Forgotten Friends, 295-296, 299; Pachuau and Van Schendel, The Camera as Witness, 121-122, 154-156, 159-160, 178, 180; Jackson, “Colonial Conquest," 68-78, 109-113. Guite suggests that when, in World War II, the Japanese appeared on the borders of Mizoram, local people were attracted to them partly because they promised to relieve them of forced labor: Jangkhomang Guite, "Representing Local Participation in INAJapanese Imphal Campaign: The Case of the Kukis in Manipur, 1943-45," Indian Historical Review 37, no. 2 (2010): 307-308.

69 Britain ratified the League of Nations' Forced Labour Convention in 1931 (ILO 1930; www .ilo.org). Its Article 18 states: "Forced or compulsory labour for the transport of persons or goods, such as the labour of porters or boatmen, shall be abolished within the shortest possible period," but proceeds to list exemptions. Colonial officials continued to use forced labor for porterage until the end of British rule in 1947. For strategies to withstand international pressures to abolish forced labor in another British colony, see Kwabena Opare Akurang-Parry, "Colonial Forced Labor Policies for Road-Building in Southern Ghana and International Anti-Forced Labor Pressures, 1900-1940," African Economic History 28 (2000): $1-25$.

$70 \quad$ Pachuau and Van Schendel, The Camera as Witness, 145-167.

71 Superintendent, Lushai Hills, 112.

72 "[E]xcept in the case of the stages below Kolasib when 12 annas [three-quarters of a rupee] a day will be paid." Superintendent, Lushai Hills, 112. Initially payments were much lower, and laborers sometimes refused to accept them as being "beneath their dignity to retain." R.B. McCabe (1892), quoted in Jackson, “Colonial Conquest," 80.

Jackson, "Colonial Conquest," 75, 122. 


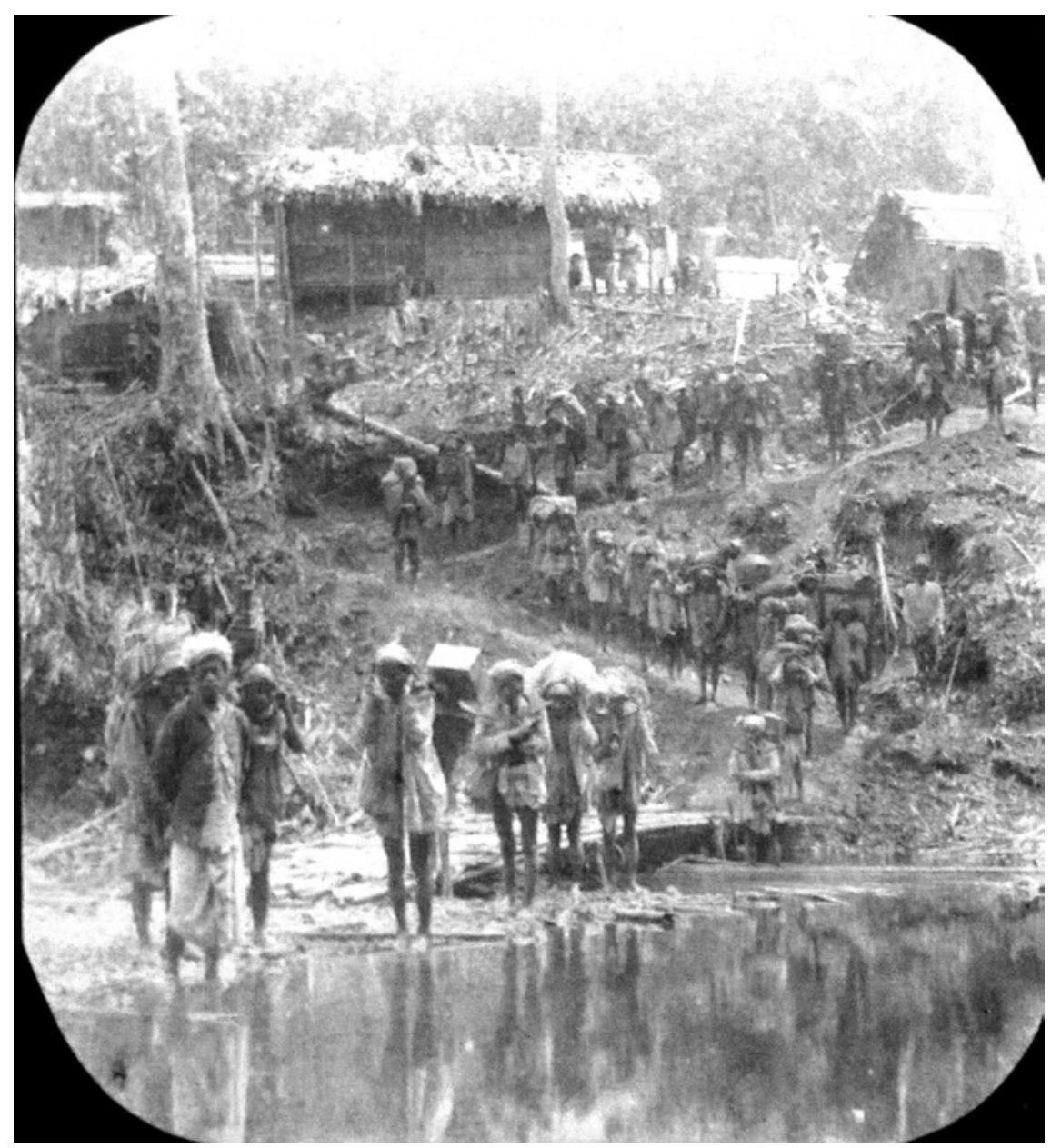

FIGURE 9.4 "Empire on their backs": More than 30 coerced porters carrying the belongings of an official on tour, 1896.

PHOTOGRAPH PROBABLY BY F.W. SAVIDGE. REPRODUCED BY PERMISSION OF THE BAPTIST CHURCH MISSION COLLECTION, SERKAWN, MIZORAM, INDIA Note: Expression taken from the title of Lipokmar Dzüvichü, "Empire on their Backs: Coolies in the Eastern Borderlands of the British Raj," International Review of Social History (2014): 89-112.

laborers in Mizoram, although they were in other parts of the mountainous frontier regions. ${ }^{74}$ However, in reality, women and children in Mizoram were at times compelled to work as porters. ${ }^{75}$ The following categories were excused

74 Superintendent, Lushai Hills, 108; Lipokmar Dzüvichü, "Empire on their Backs," 106.

75 Jackson, "Colonial Conquest," 75-76. 
from forced labor: men who went to France in World War I, government servants, those with a physical deformity, schoolmasters, chiefs and their assistants (upa), the chief's official (assistant) priest, and certain members of the Salvation Army ("on account of their industrial work and not in connection with any religious aspect of their calling"). ${ }^{76}$ In an attempt to boost cash cropping, in the early years those who started rubber plantations or potato farms were also exempted. ${ }^{77}$

Even more onerous was the notorious melveng system, introduced in $1903 .{ }^{78}$ Villages were made responsible for constructing and maintaining almost all paths, roads, and roadside camps in Mizoram. To this end, fixed labor gangs of villagers (melveng, or awmpui) were formed. These were to settle near the road for which they were responsible. They, or their village chief, were "paid twice annually at some fixed mileage rate." The authorities were very pleased with this system of forced relocation and labor exploitation, because it was cheap and efficient, and because it stimulated the market economy by "distributing money among the villagers." ${ }^{79}$

The pressure of forced labor could be so intense that people migrated to areas where they could escape it. ${ }^{80}$ Some villages in Mizoram joined the rebellion against forced labor that broke out in neighboring areas in $1917 .{ }^{81}$ Initially, the chiefs resisted the imposition of forced labor, but in the long run the system eroded their legitimacy. ${ }^{82}$ The British made them responsible for the supply of laborers, ${ }^{83}$ and because the chiefs could not protect the villagers, popular resentment converged on them.

76 Superintendent, Lushai Hills, 115-116; Parry, A Monograph, 1.

77 Pachuau and Van Schendel, The Camera as Witness, 175; Thialret, "Thialret thu," Mizo leh Vai (October 1908): 183; Jackson, "Globalising," 64; Jackson, "Colonial Conquest," 122, 187, 245. See also Parry, A Monograph, 5, 6 .

78 "Hodgkins was the first District Engineer, a very competent man who did much good work. It was under him that the Melveng system of road maintenance was brought to perfection”: J. Shakespear, "The Making of Aijal” http://aizawl.nic.in/makingofaijal.htm (July 11, 2018). Reprinted in Hluna (ed.). (2013), 410-416.

79 Superintendent, Lushai Hills, 199-201. See also Parry, A Monograph, 18; Jackson, "Colonial Conquest," 113 .

8o Darthuami, "Mihring thih tam saithuk-a," Mizo leh Vai (March 1907): 55-56; Jackson, "Colonial Conquest," 96-97, 99-100.

81 Known as Zou Gal or the Kuki Uprising. See Manju Bezbaruah, The Pursuit of Colonial Interests in India's Northeast (Guwahati, 2010), 140, 142; Guite, "Representing Local," 304.

82 Jackson, "Colonial Conquest," 92, 95-96, 99-100.

83 "Chiefs are responsible for seeing that the incidence of impressment falls evenly on all the villagers and on none more than others." Superintendent, Lushai Hills, 25, see also 33. "Every chief and Headman shall be bound to supply labour on requisition of the Superintendent or his Assistants at such rates of payment as may be fixed by the Superintendent 


\subsection{Wage Labor}

Colonial rule also ushered in wage labor. All those who were involved in the British occupation - soldiers, officials and imported laborers ${ }^{84}$-were wage earners. It was in the fortified British settlements of Aizawl and Lunglei that a cash economy first developed. ${ }^{85}$ Wage labor soon spread among the subject population as well, because the authorities encouraged it by various means. Denial of essential items was one way of compelling people to seek wage employment, as in this case (described by an early missionary) in which payment was in kind:

To bring a refractory Chief to his senses the government stopped the sale of salt in the bazaars. For the first 5 weeks did not care a straw. But when salt had all gone in their houses they began to feel the pinch. We gave out that we would pay workmen in salt (when building our house). We thus got all things up from Sairang by giving salt (we had wondered how we were going to get our good[s] up) also plenty [of] materials for building our house - simply besieged by men, women \& children bringing wood, pumpkins, sweet potatoes, beans, sugarcane, fowls, eggs, etc. in exchange for salt until our storeroom was full up \& our backyard one great pile of wood. Workmen would sleep on verandah in order to be sure of work next morning. ${ }^{86}$

In 1909, the authorities promised that those who undertook wage labor for ten days would be excused from forced labor for the year. ${ }^{87}$ Taxation was another way in which the authorities encouraged working for wages. They levied a

with the sanctions of the Governor." Superintendent, Lushai Hills, 105. See also Sailo "Economic Changes," 103. Such policies were common in colonized societies with labor shortages across the Global South. For African examples, see Akurang-Parry, "Colonial Forced Labor Policies," 5-7, 10-12; Jeremy Ball, "Colonial Labor in Twentieth-Century Angola," History Compass 3, no. 1 (2005): 3-4.

84 Soldiers came from all over South Asia; notable categories were Sikhs from the Punjab and Gorkhas from Nepal. Officials were generally from the British Isles. Imported laborers were mostly Khasis from what is now Meghalaya, Santals from Central India, Cacharis from the lowlands to the north, and Bengali boatmen.

85 Pachuau and Van Schendel, The Camera as Witness, 168-188. The commercialization of labor soon extended to hunting as well, when district authorities began offering large bounties for killing tigers, bears, leopards, and other large forest animals. Jackson, "Colonial Conquest," 135-143.

86 Pu Buanga (Lorrain) 14 March 1894.

87 H.W.G. Cole, "Hlawh-fa kuli hna thawh," Mizo leh Vai (August 1909): 133. 
household tax (and a grazing tax on some households ${ }^{88}$ ) and demanded it in cash. ${ }^{89}$ As cash would remain scarce here for decades, ${ }^{90}$ this drove numerous people to the labor market. ${ }^{91}$ Sometimes the household tax was increased to accelerate this process. ${ }^{92}$ Wage labor was greatly advanced after famine struck in 1911, because many were forced to take government loans that took years to pay off. ${ }^{93}$

British employers could be rough with wage laborers. One irate missionary admitted to beating up the boatmen who brought him to Mizoram.

You can have no idea how terribly trying Bengali boatmen are. They are the laziest set of men under the sun ... The Bengalis do not appreciate kindness. Nothing but cross words \& blows will make (many of) them do an honest day's work ... The spectacle of a missionary of Peace thrashing a poor heathen is perhaps enough to make many pious people at home shudder but I would invite such to come to spend a few years in Bengal \& see if they would not speedily resort to the same as the only way to deal with the natives, especially when they are employed as workers. ${ }^{94}$

To such employers, the practices of local laborers came as a surprise. When the first missionaries arrived in Aizawl, they found that the locals included them in their institution of hnatlang (communal labor):

Voluntary Lushai workmen come to us to help build [the] house. Everyone who sees the work says that the men have worked harder \& accomplished more in the time than they would have done for any of the officials ... They love to hear us praise what they have done \& are proud of the work they have done. They often say, 'A tha maw?' (Is it good?) and are

88 Superintendent, Lushai Hills, 104-105; Sailo, "Economic Changes," 115-116.

89 After 1904, house tax had to be paid in cash. Sailo, "Economic Changes," 205.

9o Parry, A Monograph, 2.

91 Commuting the compensation for the emancipation of bawi servants to a fee of Rs. 40 is likely to have had a similar effect.

92 "In the case of one village, Chaltlang near Aijal, the house tax was raised from Rs. 2/- to Rs. 4/- in view of the fact that in normal and prosperous times the villagers had shown themselves incapable of repaying loans taken from Government in times of distress. It is hoped that this poverty stri[c]ken people will migrate to easier conditions or if they remain will become more industrious and therefore be able to pay this enhanced rate of tax, which will reduce any future irrecoverable losses sustained by Government." Superintendent, Lushai Hills, 98.

93 Jackson, "Colonial Conquest," $278-283$.

94 Pu Buanga (Lorrain) 5 January 1895. Emphasis in the original. 
hurt if we do not praise them. It is a treat to find people take an interest in what they do. ${ }^{95}$

When the missionaries did not reciprocate and the authorities proceeded to introduce forced labor, however, the locals quickly stopped offering their labor voluntarily. Henceforth, they excluded the Europeans from their system of mutual cooperation. They worked only for cash payments or evaded employment altogether. ${ }^{96}$

After colonial annexation, the labor regime in Mizoram retained some elements of its pre-colonial precursor (see Table 9.2), but these were turned to new ends. Household self-employment remained the most prevalent, but following policies to make agriculture more market oriented (or "developed"), it became increasingly connected to a cash economy. ${ }^{97} \mathrm{New}$ cash crops (such as rice, potatoes, oranges, and rubber) linked cultivators to local and external markets, forcing adaptations in labor deployment within household production units. Servile labor had changed considerably and only one category, distress servitude, continued to thrive. Communal labor flourished, but with changes. First, the authorities restricted communal labor for the chief by curtailing the private benefits to village chiefs. Second, communal labor became the cultural idiom by which many in Mizoram understood and subsequently appropriated Christianity, allowing rapid indigenous church growth. ${ }^{98}$ This, in turn, led to some communal labor in Mizoram being channeled through British and mission-inspired associations such as the Boy Scouts, first aid groups, Sunday schools, and the Young Lushai Association. Communal labor emerged as a core element of a new identity: being a Christian Mizo.

New forms of labor dominated the colonial labor regime. The British imposed forced labor, mainly in the form of compulsory porterage and work on roads. In addition, wage labor spread rapidly, but by the end of colonial rule few people completely depended on it, and a proletarian underclass had not developed.

$95 \quad$ Pu Buanga (Lorrain) 29 January and 14 February 1894.

96 Jackson, "Colonial Conquest," 84-85, 185-186.

97 Pachuau and Van Schendel, The Camera as Witness, 171-176.

98 Hlawndo, "A Study of the Cultural Factors." 
TABLE 9.2 Mizoram. Colonial labor regime.

\begin{tabular}{|c|c|c|c|}
\hline \multicolumn{4}{|c|}{ Household labor } \\
\hline Servitude & $\begin{array}{l}\text { Servitude-by- } \\
\text { refuge (bawi) }\end{array}$ & Distress servants & $\begin{array}{l}\text { inpuichhung bawi, } \\
\text { lalchhung bawi }\end{array}$ \\
\hline \multicolumn{3}{|c|}{ Communal labor } & hnatlang \\
\hline \multicolumn{4}{|c|}{ Forced labor } \\
\hline \multicolumn{4}{|c|}{ Wage labor } \\
\hline
\end{tabular}

In 1947, India gained independence and Mizoram became incorporated into it (rather than into Burma or Pakistan, which absorbed neighboring districts). Independence had no immediate effect on labor relations, however, because the entire colonial setup continued for some time, including a British top official and rule by chiefs in the villages. Even forced labor continued: post-colonial dignitaries made use of it during their tours. ${ }^{99}$

It was not until 1955 that - after much political pressure and an electionrule by chiefs was abolished in Mizoram. ${ }^{100}$ With its disappearance, distress servitude and communal labor for the chief also became labor arrangements of the past.

Household self-employment remained important, and wage labor expanded vastly. This was a result of an increase in market-oriented production, but also of war. In 1966 an armed revolt broke out in Mizoram, and the rebels declared the area an independent republic. The Indian armed forces retaliated

99 Nari Rustomji, Enchanted Frontiers: Sikkim, Bhutan and India's Northeastern Borderlands (Calcutta, 1973), 97-98. The District Council abolished it in 1953. Zoram Hriattirna (District Information), 15 November 1952, 3, cited in Sailo, "Economic Changes," 145. India did not ratify the Forced Labour Convention of the International Labour Organisation until 1954 (ILO 1930; see also www.ilo.org).

100 J. Zorema, Indirect Rule in Mizoram 1890-1954 (The Bureaucracy and the Chiefs) (New Delhi, 2007), 169-170; Pachuau and Van Schendel, The Camera as Witness, 257. For resistance to communal labor for the chief during this period, see Sailo, "Economic Changes," $136-138$. 
with draconian measures. One that affected the majority of inhabitants was involuntary resettlement. The population of over 500 villages was driven into 110 "grouping centers" under military control. Most of the original villages were destroyed. This counterinsurgency policy affected 87 percent of Mizoram's rural population (and 82 percent of its total population). Resettlement cut people off from their fields and livelihoods, and hunger compelled them to look for wage labor or depend on government handouts. ${ }^{101}$ Many drifted into towns in search of work. Between 1961 and the end of the war in 1986, the urban population increased from 5 to 25 percent, and today more than half of the inhabitants live in cities and towns, making Mizoram one of the most urbanized states in India. By the early twenty-first century, wage work had become the dominant element of Mizoram's labor regime.

\subsection{The Return of Forced Labor}

The war also led to the reintroduction of forced labor, which had been discontinued in the $195 \mathrm{os}^{102}$ The Indian military compelled local men and women to carry loads, ${ }^{103}$ and this time there were no rules with respect to the weight of burdens, length of marches, or the treatment of porters; let alone remuneration. ${ }^{104}$ There were added dangers, too: Indian soldiers used porters as human shields against rebel attacks by having them walk between them and, if an attack happened anyway, as hostages killed in revenge. ${ }^{105}$ The "grouping centers" have been described as forced labor camps: all able-bodied internees were put to work under military supervisors and could be whipped if they disobeyed. They dug bunkers and built fences; constructed roads and cleared jungles; and carried water, food, firewood, and ammunition. ${ }^{106}$ Forced labor came to an end

\footnotetext{
101 Nunthara, Impact, 7-8, 17-18, 55-56; J.V. Hluna and Rini Tochhawng, The Mizo Uprising: Assam Assembly Debates on the Mizo Movement, 1966-1971 (Newcastle, 2012), 166, 222.

102 In 1966, Mizoram was declared a "disturbed area" under both the Assam Disturbed Areas Act of 1955 and the Armed Forces (Special Powers) Act of 1958. Neither of these acts allowed the authorities to impose forced labor. This was different in nearby Nagaland, where they actually legalized compulsory porterage in 1965 .

103 On women being forced to act as porters during the Mizoram War of Independence, see Denise Adele Ségor, "Tracing the Persistent Impulse of a Bedrock Nation to Survive within the State of India: Mizo women's response to War and Forced Migration" (Ph.D. thesis, Santa Barbara, CA, 2006), 265, 268-269, 278, 289, 327, 341, 343, 363, 384, 484.

104 Earlier generations of Indian soldiers had also mistreated porters: "The Lushais [Mizos] greatly resented having to carry what they called the sepoys' [soldiers'] 'Fat wives' and their children, while the sepoys behind them kick and beat them along the roads": McCall, Lushai Chrysalis, 288.

105 Sailo, "Economic Changes," 92-93; Hluna and Tochhawng, The Mizo Uprising, 159, 200.

106 Hluna and Tochhawng, The Mizo Uprising, 200, 158-159, 164.
} 
20 years later, with the signing of a peace treaty between the rebels and the Indian government in 1986.

\subsection{Communal Labor}

The post-colonial labor regime did not consist merely of self-employment, wage labor, and (in the early post-independence days as well as between 1966 and 1986) forced labor. It featured a special characteristic: the continued importance of unpaid voluntary communal labor. This practice had adapted to new circumstances and urban surroundings. Today, in some wealthy neighborhoods, certain recurrent forms have been replaced by wage labor, which exposes these neighborhoods to criticism about losing Mizo authenticity and the community spirit. In most neighborhoods and villages, however, voluntary communal labor continues to flourish. Local groups mobilize the labor of women, men, and children to perform tasks for the public good. These groups include churches, charitable institutions, schools, and neighborhood chapters of the Young Mizo Association (YMA). ${ }^{107}$ The technology of mobilizing voluntary labor has changed over time; from word of mouth and church gongs, to public address systems and digital social media.

Communal labor takes many forms. People gather to organize a funeral ${ }^{108}$ or a Christmas feast; construct a clinic, church, clubhouse, or private house for a family whose house has burnt down; repair a road; clean and polish; or form a rescue party in the aftermath of an earthquake or landslide (Figures 9.5 to 9.10). Communal labor may also include law and order tasks, when a group checks the neighborhood for unlawful behavior (for example, drinking). ${ }^{109}$ Lastly, groups may offer their free labor to clear an agricultural plot or wash people's blankets in return for a donation to a charitable fund. In Mizoram, voluntary labor provides a variety of services that salaried state or commercial agents take charge of elsewhere.

Compared with Mizoram's pre-colonial and colonial labor regimes (and the 20-year war regime), the post-1986 labor regime was relatively simple (see Table 9.3). Old labor relations, such as servitude and forced labor, had withered away and wage laborhad burgeoned. What remained constant throughout these three

\footnotetext{
107 The Young Lushai Association (YLA) changed its name to YMA in 1947.

108 Pachuau, Being Mizo, Ch. 5 .

109 The Mizoram Liquor (Total Prohibition) Act was in force until 2014, after which a new act allowed permit holders the consumption of alcohol under stringent conditions.
} 


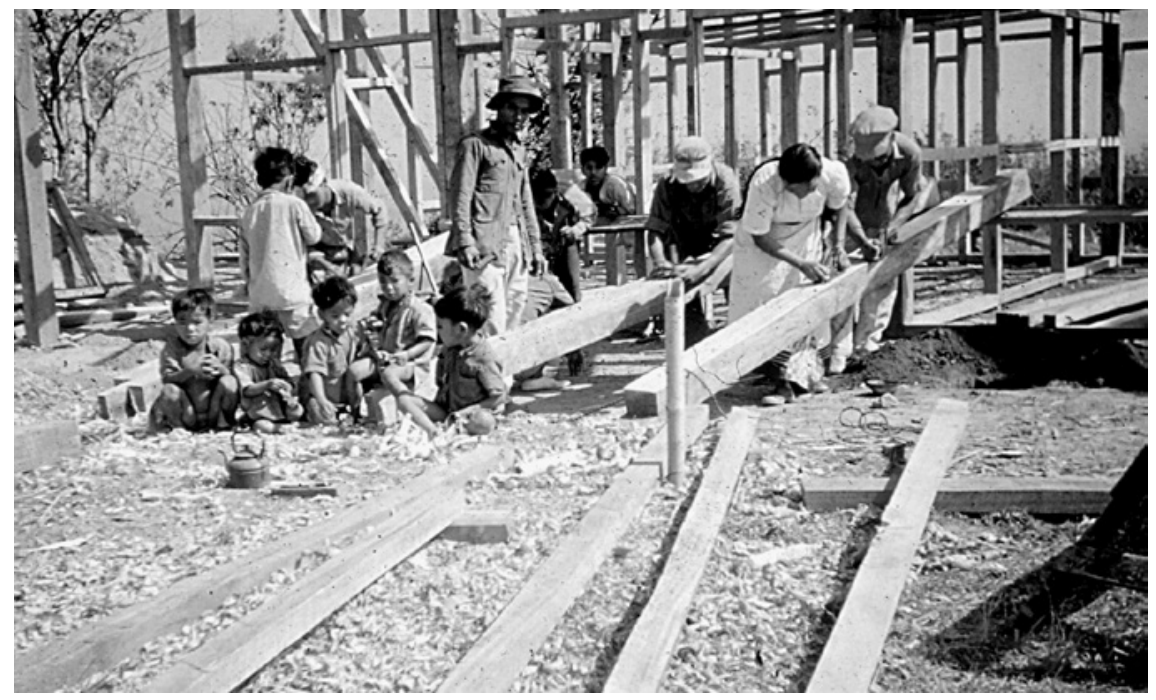

FIGURE 9.5 Communal labor. Planing planks for a new clinic in Pukzing village, 1956. PHOTOGRAPHER UNKNOWN (POSSIBLY GWEN REES ROBERTS). REPRODUCED BY PERMISSION OF AIZAWL THEOLOGICAL COLLEGE COLLECTION, AIZAWL, MIZORAM, INDIA

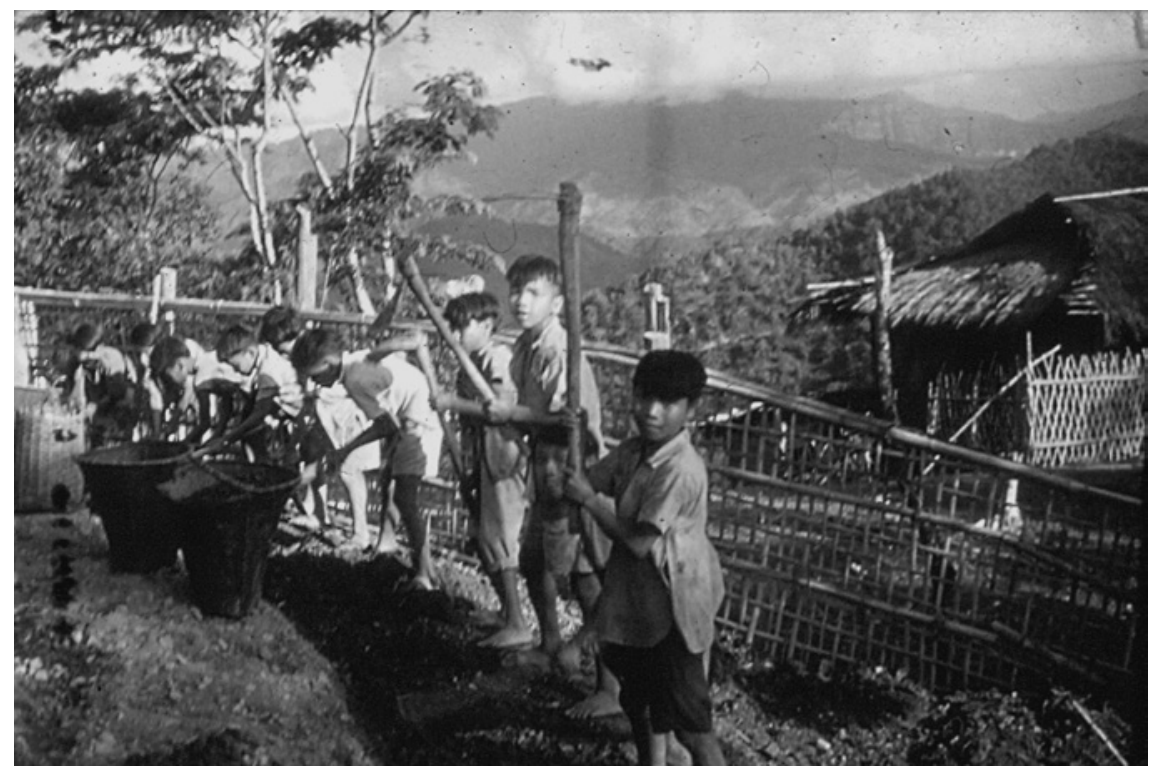

FIGURE 9.6 Communal labor. Boys repairing a road in Sihfa village, c. 1956.

PHOTOGRAPHER UNKNOWN (POSSIBLY GWEN REES ROBERTS). REPRODUCED BY PERMISSION OF AIZAWL THEOLOGICAL COLLEGE COLLECTION, AIZAWL, MIZORAM, INDIA 


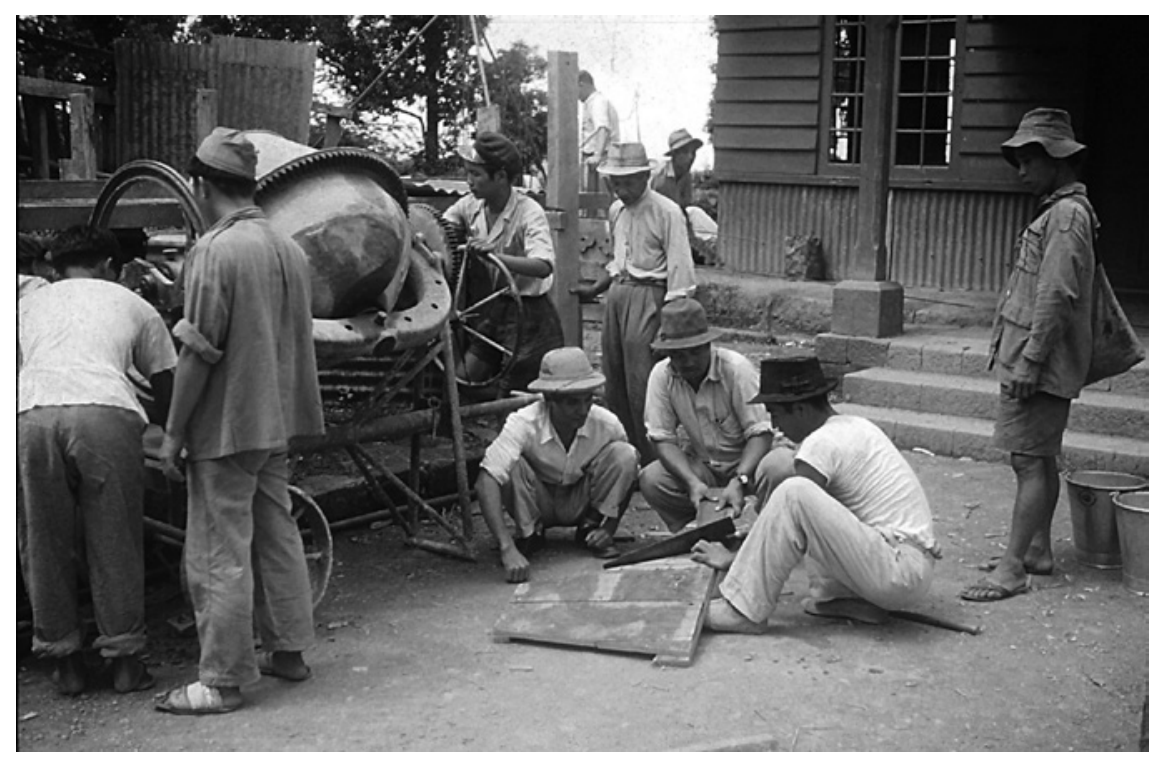

FIGURE 9.7 Communal labor. Constructing a new church in Aizawl town, 1964. PHOTOGRAPHER UNKNOWN. REPRODUCED BY PERMISSION OF LALHRUAITLUANGA RALTE COLLECTION, AIZAWL, MIZORAM, INDIA

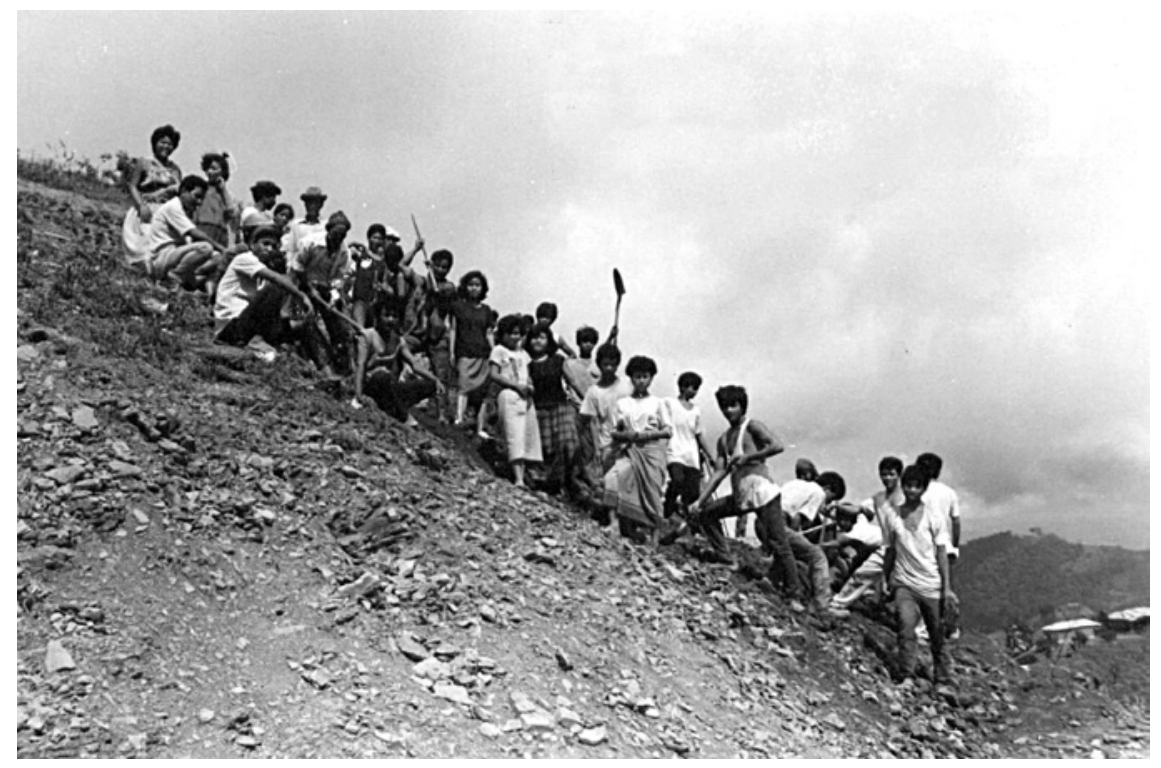

FIGURE 9.8 Communal labor. Improving the Presbyterian Hospital in Durtlang village, 1980. PHOTOGRAPHER UNKNOWN. REPRODUCED BY PERMISSION OF PRESBYTERIAN HOSPITAL COLLECTION, AIZAWL, MIZORAM, INDIA 


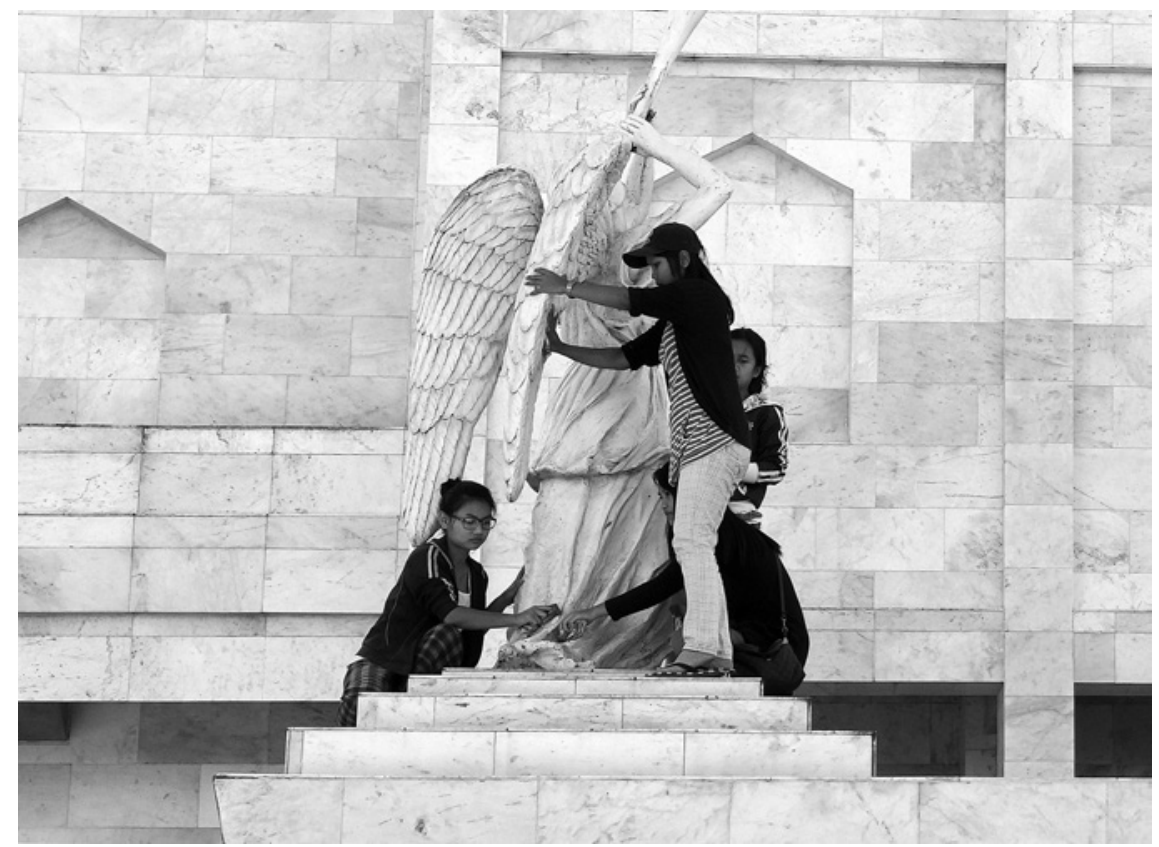

FIGURE 9.9 Communal labor. Cleaning a sacred statue in Aizawl in 2012. PHOTOGRAPH BY WILLEM VAN SCHENDEL

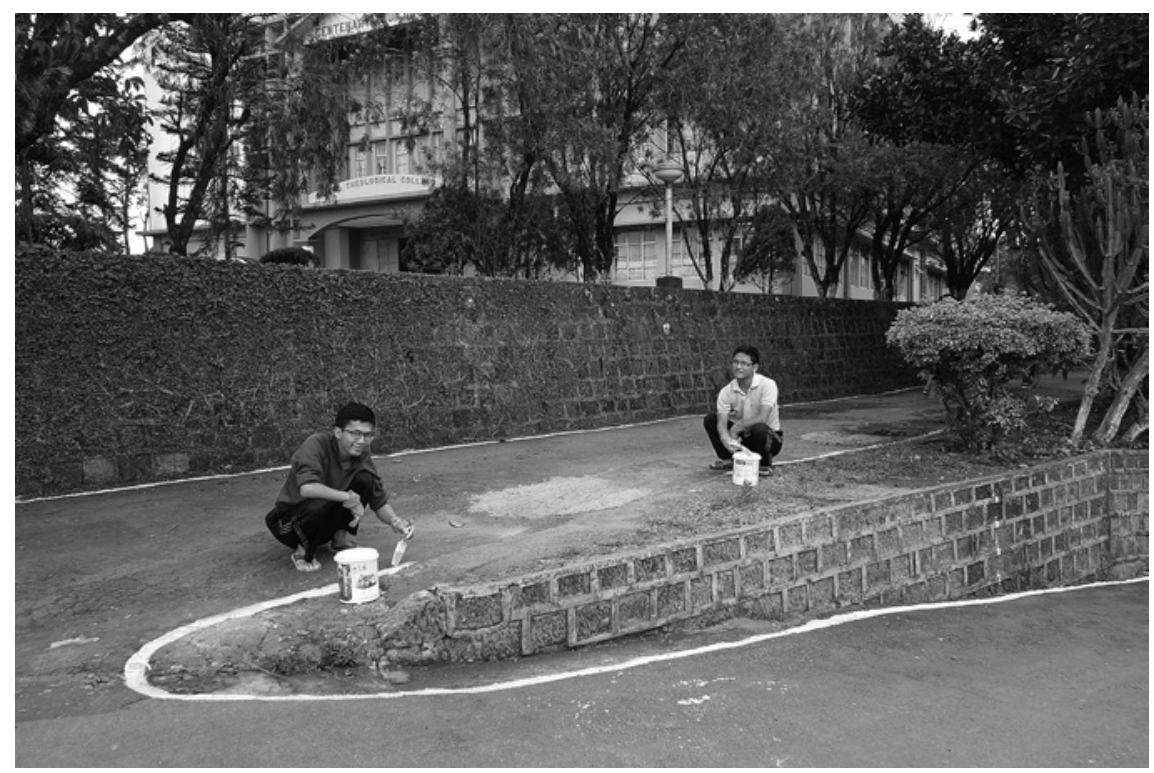

FIGURE 9.10 Communal labor. Smartening a college campus in Durtlang in 2016. PHOTOGRAPH BY WILLEM VAN SCHENDEL 
TABLE 9.3 Mizoram. Post-1955 labor regime. The period between India's independence (1947) and the abolition of chiefdom in Mizoram (1955) was a transitional one in which vestiges of servitude and forced labor persisted.

\begin{tabular}{|l|l|}
\hline Household labor \\
\hline Wage labor \\
\hline Communal labor & hnatlang \\
\hline Forced labor $(1966-1986)$ & \\
\hline
\end{tabular}

periods, however, was household self-employment and, quite remarkably, communal labor. It was this form of voluntary unpaid labor that gave the labor regime in Mizoram its singular character. The ethic of tlawmngaihna (being self-sacrificing, stoical, brave, industrious, generous, and sharing), now grounded in Christian convictions, endured as a core value. Its principal praxis wascommunity service.

Over the last 150 years, labor relations in Mizoram have undergone astonishing change. By the early twenty-first century, some forms had faded away, together with the forms of power that had supported them (servitude and communal labor for chiefs), others had been introduced (wage labor and forced labor), and yet others had endured (household labor and communal labor).

Significantly, at no time did Mizoram's labor regimes resemble those in other parts of India. In other words, any general pronouncements about labor relations in colonial or post-colonial "India" need to take on board the Mizoram case (and many others that still suffer from labor historians' "neglect, prejudice and implicit assumptions"110).

The serial imposition of forced labor - by an "authoritarian" colonial state (189os to 1950s) and by a "democratic" post-colonial state (1960s to 1980s)-is of particular interest, because it reminds us of the iterative nature of this labor relation, which signals a state's withholding of citizens' rights to certain categories of inhabitants. For this reason, the re-emergence of forced labor

110 Van der Linden, Workers of the World, 8-9. 
under post-colonial states in the wider Extended Eastern Himalayas region is of particular comparative interest. ${ }^{111}$

More than anything, however, it is the vigorous persistence of unpaid voluntary communal labor that is of distinct analytical importance. Rooted in pre-capitalist methods of production, it survived the transition from rural to urban, from barter to cash, and from high levels of autarky to a market economy. Today it coexists with wage labor and household subsistence labor.

As we have seen, voluntary communal labor (hnatlang) is an economic activity that expresses the ethical code of tawmngaihna; to be self-sacrificing, stoical, brave, industrious, generous, and sharing. Figure 9.11 invokes this code as the essence of being Mizo. We have also seen that communal labor became

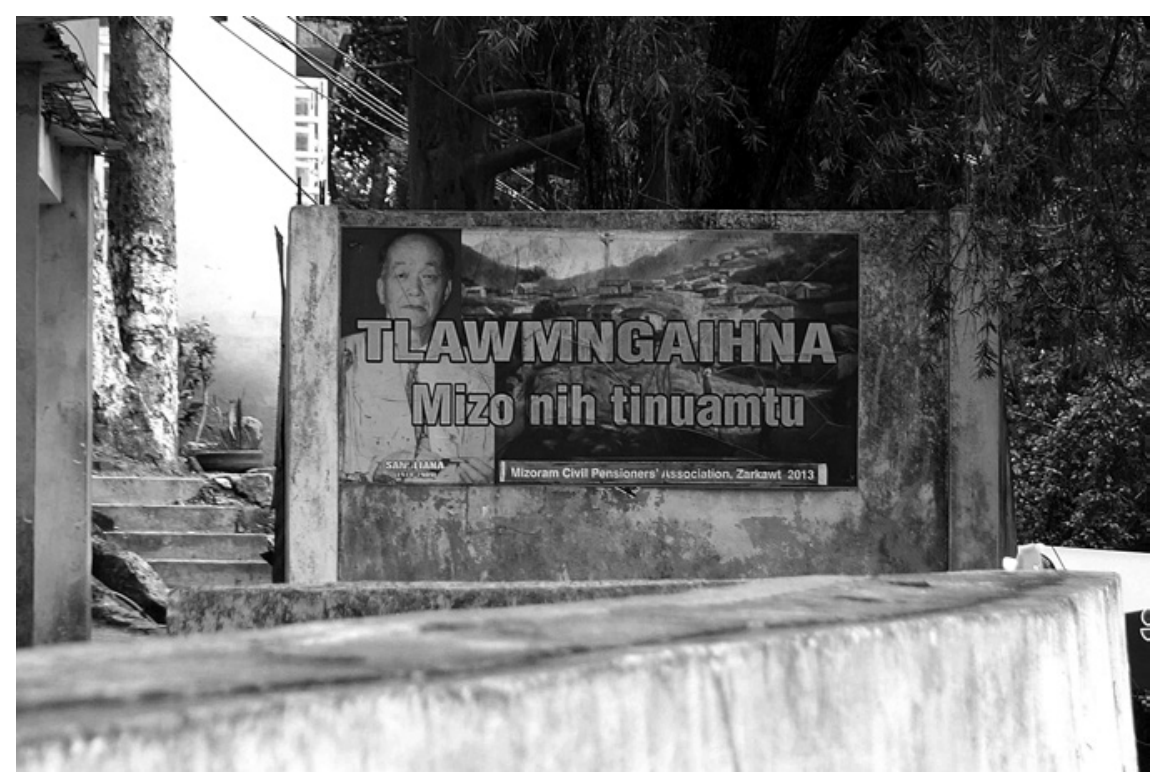

FIGURE 9.11 "Tlawmngaihna is what makes being Mizo so wonderful!" Roadside poster in Durtlang (Mizoram), 2016.

PHOTOGRAPH BY WILLEM VAN SCHENDEL

111 The best-studied example is Burma (Myanmar). See Patrick Bollé, "Supervising Labour Standards and Human Rights: The Case of Forced Labour in Myanmar (Burma)," International Labour Review, 137 no. 3 (1998): 391-418; : Karen Women Organization, Walking Amongst Sharp Knives: The Unsung Courage of Karen Women Village Chiefs in Conflict Areas of Eastern Burma (Mae Sariang, 2010); Richard Horsey, Ending Forced Labour in Myanmar: Engaging a Pariah Regime (Abingdon, Oxon, 2011); Ken Maclean, "Lawfare and Impunity in Burma since the 2000 Ban on Forced Labour," Asian Studies Review 36, no. 2 (2012): 189-206. 
the cultural idiom by which many in Mizoram understood and appropriated Christianity. ${ }^{112}$ Today the code of tlawmngaihna forms the core of the selfascribed identity of Mizo Christians (or Christian Mizos). ${ }^{113}$

In recent decades, the salience of Mizo self-ascription has increased because of mainland Indian insistence on Mizo "tribal" differences, and because of the 20-year armed struggle for independence. Today, communal labor is a manifestation of proud self-sufficiency and religious merit. To see people routinely offering their labor power for the public good is especially striking in an era in which neo-liberal policies-in India as elsewhere-seek to spread a free-market form of capitalism that encourages a calculus of individual gain.

\section{Communal Labor and the Reach of "Global Labor History"}

Is voluntary communal labor to be studied as part of "global labor history"? Marcel van der Linden defines the field as researching "not the history of all forms of human labor through the centuries, but the history of labor insofar that labor is part of the global process of commodification." 14 However, theorizing voluntary communal labor as being "part of the global process of commodification" is a bit of a stretch. It is not commodified. As a rule, it does not produce commodities. Nor does it generate commodity production or incubate wage labor. It has held out amidst the rise of wage labor and commodity production, but it is of a different order. It presents global labor historians with some conceptual issues. Does contemporary Mizoram fit the assumptions about a "capitalist society," and if so, since when; and how should we deal analytically with non-commodified labor at its very core? Further, how should we calibrate economic and cultural aspects in explaining the persistence of communal labor?

Social scientists have sought to explain unpaid voluntary work in various ways: As an individual "conscience good," as an expression of "warm-glow" non-market transfers, or as embedded in global development interventions. ${ }^{115}$

\footnotetext{
112 Hlawndo, "A Study of the Cultural Factors."

113 Pachuau, Being Mizo.

114 Van der Linden, Workers of the World, ${ }_{366-367}$ (emphasis in the original).

115 For introductions, see Lorenzo Cappellari and Gilberto Turati, "Volunteer Labour Supply: The Role of Workers' Motivations," Annals of Public and Cooperative Economics 75, no. 4 (2004): 619-643; Deborah A. Schmedemann, "Pro Bono Publico as a Conscience Good," William Mitchell Law Review 35, no. 3 (2008-2009): 977-1010; Ruth J. Prince, "Seeking Incorporation? Voluntary Labor and the Ambiguities of Work, Identity, and Social Value in Contemporary Kenya," African Studies Review 58, no. 2 (2015): 85-109; Sergio Destefanis
} 
Labor historians have focused mainly on the entanglement of wage labor and unpaid household labor for subsistence and the reproduction of labor power. ${ }^{116}$ This is what makes the case of Mizo - and others like it across the world ${ }^{117}$ - so interesting. Those who regularly offer their labor power for hnatlang see this as a free contribution to the community, as a labor of love, and as a confirmation of cultural identity. Their labor is not for personal use nor for close kin, but for a wider community with which they identify: village, urban neighborhood, association, church, and ultimately, Mizo nation (hnam). Communal labor does not sustain people's own households, nor is it a survival strategy. Further, it is voluntary: redistributive pressure is low and sanctions for non-involvement are minimal. ${ }^{118}$ Moreover, participants in hnatlang cannot be subsumed under the rubrics of the "working poor" or "subaltern workers." They have all kinds of class positions and degrees of autonomy (wage laborers, housewives, unemployed, employers, and self-employed).

Voluntary labor poses questions about basic concepts in global labor history: the transformative force of capitalism, extra-economic coercion, peripheral areas, ${ }^{119}$ the degree of commodification that makes a society capitalist, and

and Marco Musella, eds., Paid and Unpaid Labour in the Social Economy: An International Perspective (Heidelberg, 2009). These deal with non-profit ("third-sector") organizations and "social enterprises," rather than with the type of unpaid voluntary labor addressed in this chapter.

116 For example, the Bielefeld or Entanglement School, which evolved out of the modesof-production debate. Van der Linden, Workers of the World, 320-337. In the "Taxonomy of Labour Relations," an ongoing venture aiming to categorize labor relations worldwide over the past 500 years, there is as yet no place for communal labor relations of the type encountered in Mizoram; instead the taxonomy links "reciprocal labor" to households: Global Collaboratory on the History of Labour Relations, 1500-2000, 2015, Taxonomy of Labour Relations, http://www.historyoflabourrelations.org. (July 11, 2018).

117 For example, tequio in Mexico and vuimi/kikwa in Tanzania: Danièle Dehouve, "Le travail gratuit au Mexique: Les communautés tlapanèques et l'équipement," Études rurales 113/114 (1989): 119-130; Michael J. Sheridan, "An Irrigation Intake Is Like a Uterus: Culture and Agriculture in Precolonial North Pare, Tanzania," American Anthropologist 104, no. 1 (2002).

118 For a definition of voluntary labor for statistical purposes ("the measurement of volunteer work"), see ILO, Report of the Conference, 18th International Conference of Labour Statisticians Geneva, 24 November-5 December 2008 (Geneva: International Labour Organisation), 18-19.

119 According to Wallerstein, free labor is "a defining feature of capitalism, but not free labor throughout the productive enterprises. Free labor is the form of labor control used for skilled work in core countries whereas coerced labor is used for less skilled work in peripheral areas." Immanuel Wallerstein, The Modern World System I: Capitalist Agriculture and the Origins of the European World-Economy in the Sixteenth Century (Berkeley etc., 1974), 127. 
collective action. For example, could we interpret voluntary labor as collective action; as a form of resistance against expansive capitalism? Such questions promise new dialogues and insights, especially regarding the balancing of economic and cultural factors in explaining labor relations in the world today. As Hagan and Wells point out in a review of conceptual debates about free and unfree labor: "Workers are as steeped in the cultural meanings derived from language, religion, ethnicity, and gender as in those created by their location in the relations of production."120

If we find it hard to see communal labor as part of "the global process of commodification," it can only be part of what Van der Linden calls "the history of all forms of human labor through the centuries." He emphasizes that these two research domains are compatible, but not of equal urgency. It is a question of priority. "If Global Labor History would in time extend its horizons beyond capitalist civilization, it would deepen our understanding of the specificity (or non-specificity) of capitalist developments." ${ }^{21}$ His motivation for endorsing this time lag is twofold:

both Old and New labor historians have always centrally focused on labor in capitalist societies; it is obvious that Global Labor History dovetails with that interest ... [The] approach directly contributes to understanding the world in which we live now - to [offer] better insight into the tendencies which have brought us to where we are today. ${ }^{122}$

Both points exemplify the theoretical and methodological challenges that Van der Linden elucidates so skillfully. Furthermore, both merit a discussion that goes well beyond the scope of this chapter. The first contains a tactical warning: if we broaden the field of global labor history to include the history of all forms of human labor through the centuries, we run the risk of forfeiting labor historians' attention. However, why should global labor history wait for "Old and New labor scholars" to be ready? Should their current interests really constrain the pursuit of global labor history, at least for some time to come? It might be better to face up to the tension between the ambition to "write the history of labor on a world scale"123 and its provisional delimitation to "the global process of commodification."

120 Jim Hagan and Andrew Wells, "Brassed-Off: The Question of Labour Unfreedom Revisited," International Review of Social History 45 (2000): 484.

121 Van der Linden, Workers of the World, 361.

122 Van der Linden, Workers of the World, 360.

123 Van der Linden, Workers of the World, 360. 
The second point begs the question of who the "we" are in the phrase "the tendencies which have brought us to where we are today." Presumably, this is a worldwide "we" that includes present-day Mizoram society and its thriving practice of unpaid voluntary communal labor. In other words, if labor historians doubt whether unpaid voluntary communal labor appertains to the global process of commodification, they can only study it by stepping out of their comfort zone. It seems impracticable counsel to neglect non-commodified labor relations until the field of global labor history is ready "in time ... to extend its horizons."

Marcel van der Linden's clarion call for "more accurate typologies from careful empirical study of labor relations" is well taken, as is his assertion that we need to abandon teleological perspectives in order to study the histories of labor as an "open dialectic" without fully predetermined outcomes. ${ }^{124}$ But does this not necessarily broaden the field to the history of labor on a world scale, without preconditions or restrictions? How else can we overcome the field's "implicit assumptions"? ${ }^{125}$ Surely, global labor history is too important to have us wait for historians to reach agreement on what type, or degree, of commodification makes a society capitalist; or on how to delineate "the global process of commodification." Let us broaden the comfort zone of global labor history to comprise analyses of all histories of labor.

124 Van der Linden, Workers of the World, $36,369$.

125 Van der Linden, Workers of the World, 8-9, 28-32. 